\title{
Field Comparison of Five In Situ Turbidity Sensors
}

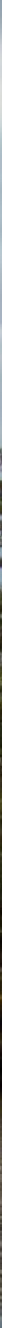

U.S. Department of the Interior

U.S. Geological Survey 
Cover photograph. East Pearl River, Stennis Space Center, Mississippi. Photograph by Teri T. Snazelle, U.S. Geological Survey. 


\section{Field Comparison of Five In Situ Turbidity Sensors}

By Teri T. Snazelle

Open-File Report 2020-1123 


\title{
U.S. Department of the Interior \\ DAVID BERNHARDT, Secretary
}

\author{
U.S. Geological Survey \\ James F. Reilly II, Director
}

U.S. Geological Survey, Reston, Virginia: 2020

For more information on the USGS - the Federal source for science about the Earth, its natural and living resources, natural hazards, and the environment-visit https://www.usgs.gov or call 1-888-ASK-USGS.

For an overview of USGS information products, including maps, imagery, and publications, visit https://store.usgs.gov/.

Any use of trade, firm, or product names is for descriptive purposes only and does not imply endorsement by the U.S. Government.

Although this information product, for the most part, is in the public domain, it also may contain copyrighted materials as noted in the text. Permission to reproduce copyrighted items must be secured from the copyright owner.

Suggested citation:

Snazelle, T.T., 2020, Field comparison of five in situ turbidity sensors: U.S. Geological Survey Open-File Report 2020-1123, 15 p., https://doi.org/10.3133/ofr20201123.

Associated data for this publication:

Snazelle, T.T., 2020, Turbidity data collected by five in situ sensors at USGS site 02492620 Pearl River at NSTL station, MS from November 2017 to January 2018: U.S. Geological Survey data release, https://doi.org/10.5066/P9KDERG6.

U.S. Geological Survey, 2018, USGS water data for the Nation: U.S. Geological Survey National Water Information System database, https://doi.org/10.5066/F7P55KJN.

ISSN 2331-1258 (online) 


\section{Contents}

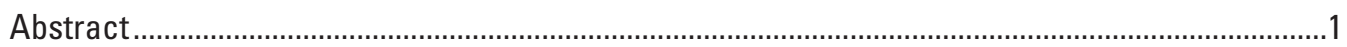

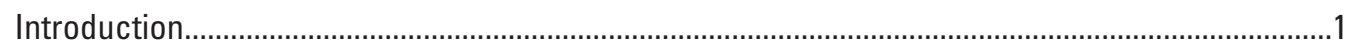

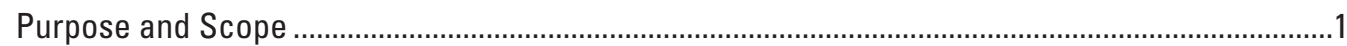

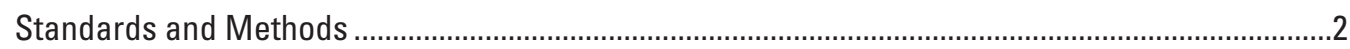

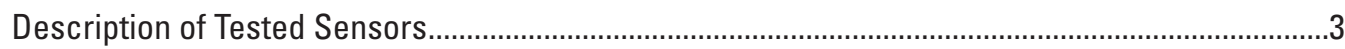

Field Deployment at U.S. Geological Survey Site 02492620 Pearl River at National Space

Technology Laboratories Station ...............................................................................

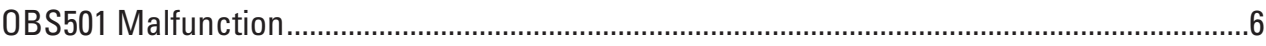

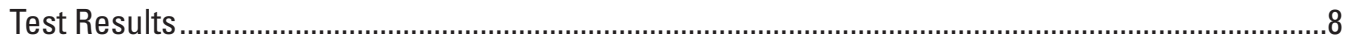

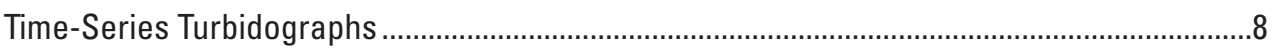

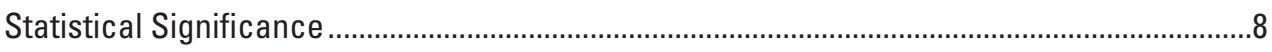

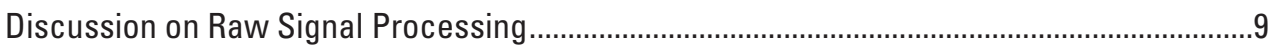

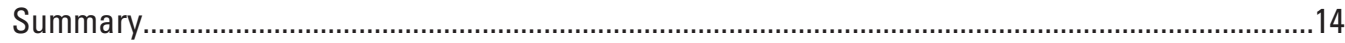

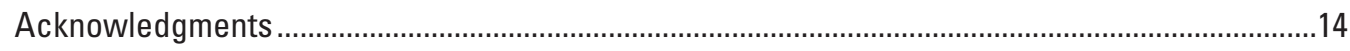

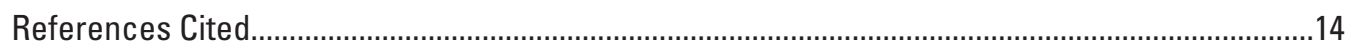

\section{Figures}

1. Map showing the location of Pearl River at National Space Technology

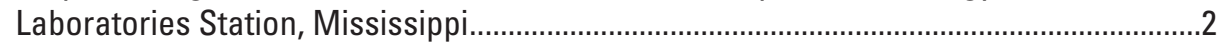

2. Photograph showing Xylem EXO turbidity sensor .............................................................

3. Photograph showing Hach Solitax sc turbidity sensor .....................................................

4. Photograph showing In Situ Aqua TROLL 600 turbidity sensor...........................................

5. Photograph showing Campbell Scientific OBS501 turbidity sensor ...................................

6. Photograph showing Observator ANALITE NEP-5000 turbidity sensor .............................5

7. Photographs showing Pearl River at National Space Technology Laboratories Station, Mississippi, and tank assembly .............................................................................

8. Photograph showing the tank with lid showing predrilled sensor holes ............................7

9. Photographs showing the Campbell Scientific OBS501 turbidity sensor after

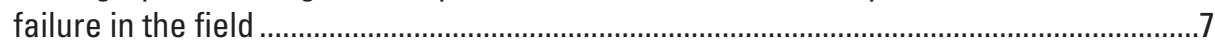

10. Graph showing time series showing the close trending of data produced by the five turbidity sensors.

11. Graph showing modified time series showing the data produced by four turbidity sensors after data from the malfunctioning OBS501 was removed....................9

12. Pairwise plots showing in situ data from the Xylem EXO, Hach Solitax sc, In Situ Aqua TROLL 600, and Observator ANALITE NEP-5000 turbidity sensors showing the correlation to each other.

13. Regression plots comparing in situ turbidity data to the Hach $2100 \mathrm{~N}$-measured discrete turbidity, in formazin nephelometric units. 


\section{Tables}

1. Features and specifications on tested turbidity sensors

2. Discrete turbidity data and corresponding sensor measurements, in formazin nephelometric units.

3. Statistical distribution at 95-percent confidence of differences between sensor measurements and Hach $2100 \mathrm{~N}$-measured discrete samples, in formazin nephelometric units.

4. Statistical summary from the differences between the EXO, Solitax, TROLL 600 , and NEP-5000-measured turbidity, and the results of the discrete samples collected concurrently and measured on the Hach $2100 \mathrm{~N}$.

5. Results from the single factor analysis of variance test at 95 -percent confidence.........12

6. Results from the Tukey Honestly Significant Difference test at 95-percent confidence

\section{Conversion Factors}

International System of Units to U.S. customary units

\begin{tabular}{lcc}
\hline Multiply & By & To obtain \\
\hline & Length & \\
\hline nanometer $(\mathrm{nm})$ & 0.00000003937 & inch (in.) \\
\hline
\end{tabular}

Temperature in degrees Celsius $\left({ }^{\circ} \mathrm{C}\right)$ may be converted to degrees Fahrenheit $\left({ }^{\circ} \mathrm{F}\right)$ as follows:

$$
{ }^{\circ} \mathrm{F}=\left(1.8 \times{ }^{\circ} \mathrm{C}\right)+32
$$

\section{Supplemental Information}

Turbidity is given in formazin nephelometric units (FNU) or nephelometric turbidity units (NTU).

\section{Abbreviations}

$\begin{array}{ll}\text { ANOVA } & \text { analysis of variance } \\ \text { HSD } & \text { Honestly Significant Difference } \\ \mathrm{Hz} & \text { Hertz } \\ \text { ISO } & \text { International Organization for Standardization } \\ \text { RS } & \text { recommended standard } \\ \text { SDI-12 } & \text { serial data interface at 1,200 baud } \\ \text { SDVB } & \text { styrene divinylbenzene } \\ \text { Sn } & \text { serial number } \\ \text { USGS } & \text { U.S. Geological Survey }\end{array}$




\title{
Field Comparison of Five In Situ Turbidity Sensors
}

\author{
By Teri T. Snazelle
}

\begin{abstract}
Five commercially available turbidity sensors were field tested by the U.S. Geological Survey Hydrologic Instrumentation Facility for accuracy and data comparability. The tested sensors were the Xylem EXO (EXO), the Hach Solitax sc (Solitax), the In Situ Aqua TROLL sensor installed onto a TROLL 600 sonde (TROLL 600), the Campbell Scientific OBS501 (OBS501), and the Observator ANALITE NEP-5000 (NEP-5000). The sensors were deployed at Pearl River at National Space Technology Laboratories Station, Mississippi (U.S. Geological Survey site 02492620), and were serviced weekly. In addition to the five in situ turbidity sensors, corresponding discrete samples were collected and analyzed during the evaluation on a calibrated Hach $2100 \mathrm{~N}$ benchtop turbidimeter. The OBS501 malfunctioned early in the evaluation and eventually failed, resulting in few data from the sensor.

During this study, the four remaining sensors (minus the OBS501) changed similarly throughout the field test; however, sensor data from the EXO consistently demonstrated lower results than the Solitax, TROLL 600, and NEP-5000, possibly because of the variation in raw signal processing among manufacturers. Results from a single factor analysis of variance test and a Tukey Honestly Significant Difference test verified the low bias observed in the EXO data and indicated there was a significant difference between the EXO data and data from the Solitax, TROLL 600, and NEP-5000 but an insignificant difference among the data when the Solitax, TROLL 600, and NEP-5000 were compared to each other.
\end{abstract}

\section{Introduction}

Turbidity is a measure of water clarity and is an important indicator of environmental health (Ziegler, 2002). Turbid water will appear cloudy from the presence of suspended solids such as soil particles, algae, microbes, and other substances in the water column. The turbidity of a body of water is determined by measuring how much the material or suspended solids in the water reduce or scatter the passage of light through the water column (American Public Health Association, 2012); however, turbidity is not a direct measurement. Therefore, the process of obtaining accurate measurements, and the proper interpretation of those measurements, can be challenging.
The U.S. Geological Survey (USGS) Hydrologic Instrumentation Facility evaluates the performance of instrumentation used to collect hydrologic data. Evaluations are done primarily to determine if devices of interest would be suitable for use by USGS personnel for hydrologic data collection; however, reports describing the instrument evaluation results do not represent an endorsement by the USGS of the tested instrument. Evaluation reports document the results at the time of testing and may or may not represent future conditions resulting from manufacturer's updates and improvements.

This report describes the field testing of five commercially available turbidity sensors at Pearl River at National Space Technology Laboratories Station, Mississippi (USGS site 02492620) (fig. 1).

The turbidity sensors evaluated in this study were the Xylem EXO (EXO), the Hach Solitax sc (Solitax), the In Situ Aqua TROLL sensor installed onto a TROLL 600 sonde (TROLL 600), the Campbell Scientific OBS501 (OBS501), and the Observator ANALITE NEP-5000 (NEP-5000). Accuracy refers to the closeness of a measured value to a known value or reference. Defining the accuracy of a turbidity sensor can be difficult because manufacturers often misunderstand the concept of referencing a sensor to formazin standards to call it an International Organization for Standardization 7027-compliant instrument (ISO 7027-1) (Anderson, 2005; Hughes and others, 2019; Lewis and others, 2006). For this study, accuracy was assessed by comparing the sensor-measured turbidities to the results of concurrently collected discrete samples measured on a calibrated Hach $2100 \mathrm{~N}(2100 \mathrm{~N})$ benchtop turbidimeter. Data generated during this study are available in a USGS data release (Snazelle, 2020).

\section{Purpose and Scope}

The primary purpose of the study was to demonstrate the ability of five sensors to provide qualitatively similar data and to determine that instream measurement variability can occur not only because of differences in sensor design or optical configuration but could also be due to manufacturer practices in internal signal processing. Measured closeness or "accuracy" of the sensors was determined by comparing uncorrected 


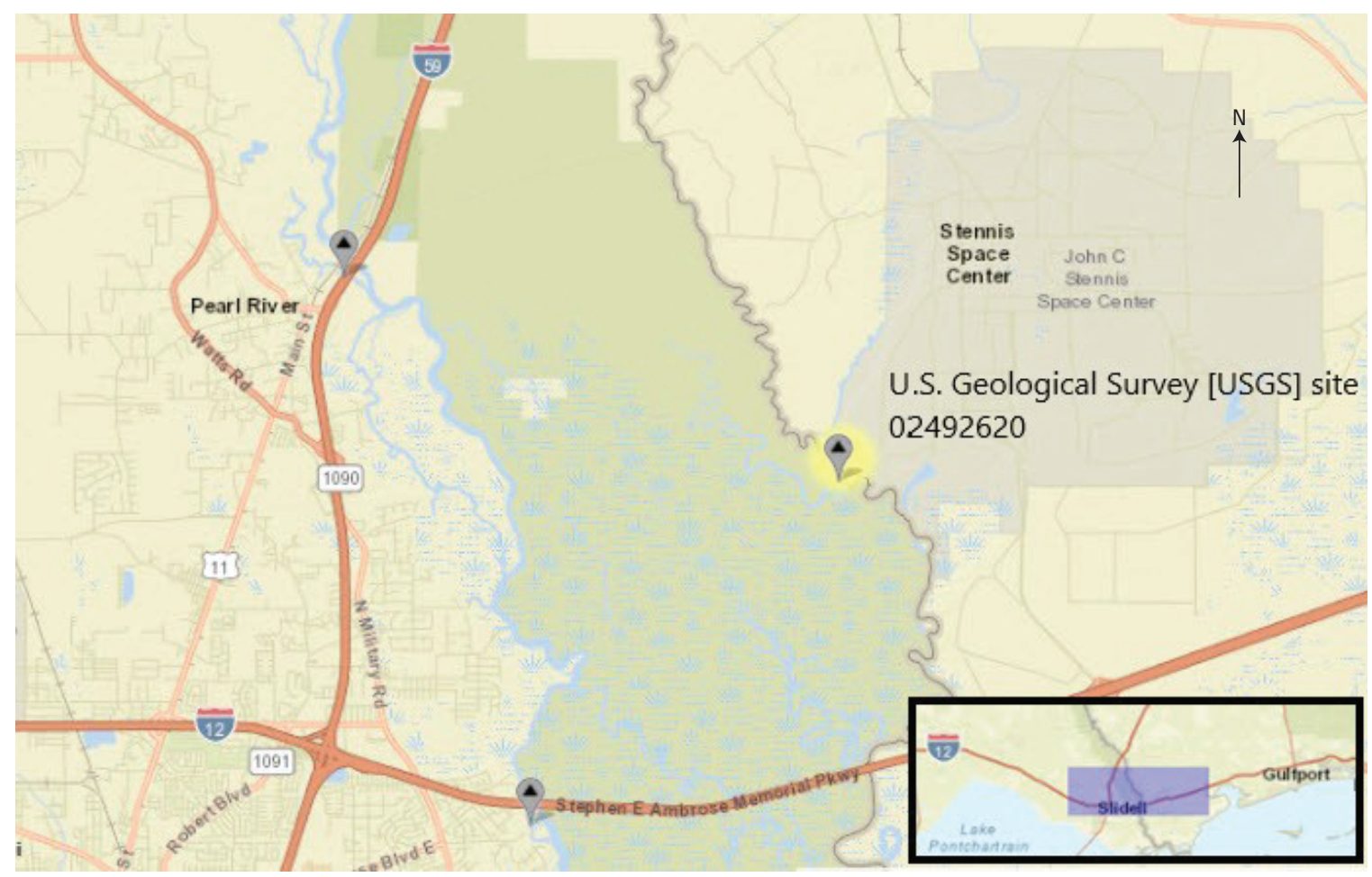

Figure 1. Location of Pearl River at National Space Technology Laboratories Station, Mississippi (U.S. Geological Survey site 02492620).

sensor-measured turbidity to corresponding discrete samples collected concurrently during the testing period and analyzed on a calibrated benchtop $2100 \mathrm{~N}$ turbidimeter operated in ratio mode with averaging (Hach Company, 2014). The percentage difference was calculated as follows:

$$
\% \text { difference }=\frac{\text { sensor measured in situ turbidity in } F N U-2100 N \text { measured discrete turbidity in } F N U}{2100 N \text { measured discrete turbidity in } F N U} * 100
$$

where

$$
\begin{aligned}
\% \text { difference } & \text { is percentage difference and } \\
\text { FNU } & \text { is formazin nephelometric units. }
\end{aligned}
$$

Because difference was determined by in situ data minus the $2100 \mathrm{~N}$ measurements, positive values indicated a high bias in the sensor data as compared to the $2100 \mathrm{~N}$, and negative values indicated a comparatively low bias. After a brief description of each turbidity sensor in the study, the test procedures and results are described.

\section{Standards and Methods}

The most commonly accepted guide for turbidity measurement is the ISO 7027-1. The ISO 7027-1 describes two principles of turbidity determination; nephelometry, or the measurement of diffused (scattered) radiation, and turbidimetry, the measurement of attenuated (absorbed) radiant flux. Nephelometry is the principle used by most modern in situ sensors, including the five sensors in this study. The ISO 7027-1 defines the nephelometer as one with the following features:

- a monochromatic light source such as a light-emitting diode,

- a detection angle that is 90 plus or minus $( \pm) 2.5$ degrees from the lamp,

- an aperture angle between 20 and 30 degrees, and

- a spectral peak range from 830 to 890 nanometers (nm). 
A sensor is considered compliant to the definition of a nephelometer if the primary detector is at 90 degrees from the lamp; however, a sensor may have a secondary detector configuration and still be considered compliant (International Organization for Standardization, 2016).

The ISO 7027-1 defines the acceptable reference suspensions for diffuse-radiation (scatter) calibration as formazin stock suspension and stabilized formazin suspensions such as StablCal. Alternatively, styrene-divinylbenzene (SDVB) bead suspensions, such as AMCO Clear or YSI-brand turbidity standards, may be used as secondary standards, but their equivalency to a freshly prepared formazin standard must be verified semiannually by testing the secondary standard in triplicate at five suspension levels. (International Organization for Standardization, 2016). All sensors evaluated in the study are compliant to the optical requirements specified in the ISO 7027-1 for a nephelometer; however, not all the sensors met the ISO 7027-1 requirement for calibration. The EXO, Solitax, and TROLL 600 turbidity sensors were calibrated using formazin and stabilized formazin suspensions. The OBS501 and the NEP-5000 were factory calibrated with SDVB standards. Before deployment, the calibration of each sensor was verified with concentration-verified formazin and StablCal solutions. Formazin reference solutions including formazin dilutions and StablCal formazin-based reference standards are also subject to error with a typical accuracy of \pm 5 percent of the stated reference value.

The $2100 \mathrm{~N}$ was used to measure the turbidity of discrete samples collected at USGS site 02492620 . The $2100 \mathrm{~N}$ is considered an industry standard for the measurement of turbidity, and it has a different optical configuration with the following features:

- a white or broadband (400-680 nm) light source (tungsten) and

- a single detector, 90 degrees from the lamp.

Differences between the instream readings of the ISO 7027-compliant sensors are well documented (Hughes and others, 2019).

\section{Description of Tested Sensors}

The EXO turbidity sensor is a nephelometric sensor that uses a near-infrared light source with a spectral range from 845 to $875 \mathrm{~nm}$ (Xylem, 2019). The sensor does not have a built-in wiper, and users are encouraged to install the sensor onto an EXO2 or EXO3 water-quality sonde equipped with a central wiper to reduce biofouling. Communication protocols for the EXO1, EXO2, and EXO3 sondes include serial data interface at 1,200 baud (SDI-12), Recommended Standard (RS)-232, RS-485, and Bluetooth. The operating range of the EXO turbidity sensor is from 0.01 to 4,000 formazin nephelometric units (FNU) based on a 3-point calibration with YSIbranded SDVB standards (Xylem, 2019). Note that there is no
4,000 SDVB standard sold by Xylem to validate the sensor maximum of 4,000 FNU and sensor checks in 4,000 formazin solution indicate the sensor is not formazin referenced greater than $1,010 \mathrm{FNU}$. The degree of error in the turbidity range from 1,010 to 4,000 FNU varies among the lots of EXO sensors. The EXO turbidity sensor in the study was serial number (sn) 14J103807, installed onto an EXO2 sonde, sn 12H100762 (fig. 2). Communication to the sonde and sensor was managed through Xylem's KOR software, version 1.0.12. The sensor firmware version was 3.0.0.

The Solitax is a sensor that uses dual infrared light sources with a spectral wavelength of $860 \mathrm{~nm}$ (fig. 3). The sensor has photoreceptors that detect light 90 degrees from the light source and 140 degrees from the light for backscatter detection of heavy suspension. The Solitax contains a self-cleaning wiper to reduce biofouling and is designed to be operated with the Hach sc controller to provide output options including analog, Modbus RS-485, Profibus, or Hart. The operating range of the Solitax is from 0.001 to 4,000 nephelometric turbidity units (NTU; Hach Company, 2017). The Solitax used in the study was sn 1718695 . The software version of the sensor at the time of testing was 2.21 with firmware version 2.

The TROLL 600 sensor is used on the TROLL 600 and TROLL 500 multiparameter sondes. It is a sensor with a single light-emitting diode light source with a spectral wavelength of $855 \mathrm{~nm}$. The TROLL 600 has two detectors, the primary detector and the reference detector, that detect light 90 degrees from the light source (fig. 4). The sensor is designed to be used with the sonde's central wiping system for biofouling control. The TROLL 500 and 600 sondes have several communication modes including SDI-12, RS-232, Modbus, and Bluetooth. The operating range is from 0.01 to 4,000 NTU (In Situ, Inc.,

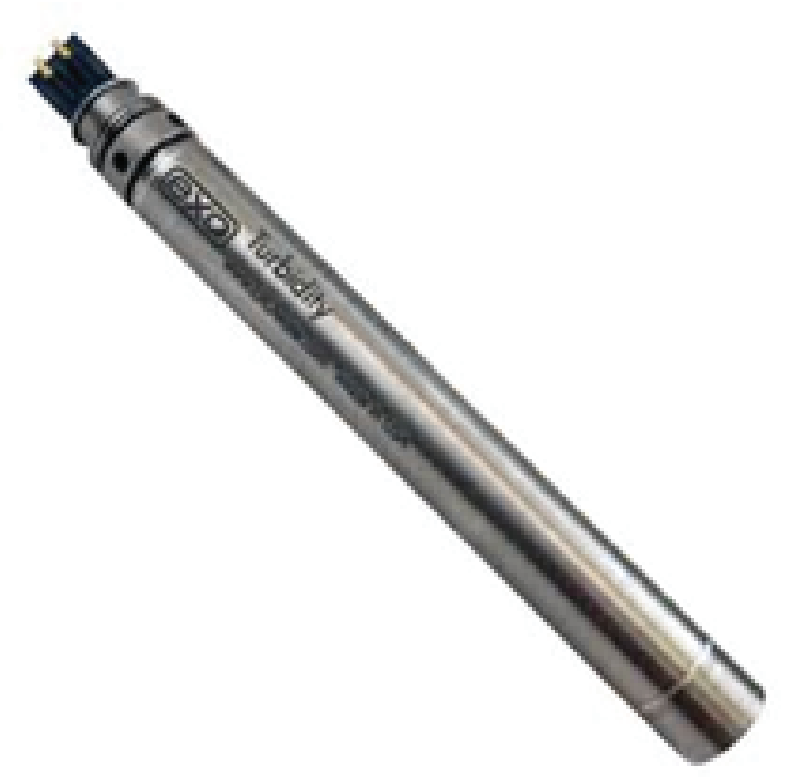

Figure 2. Xylem EXO turbidity sensor (used with permission). 


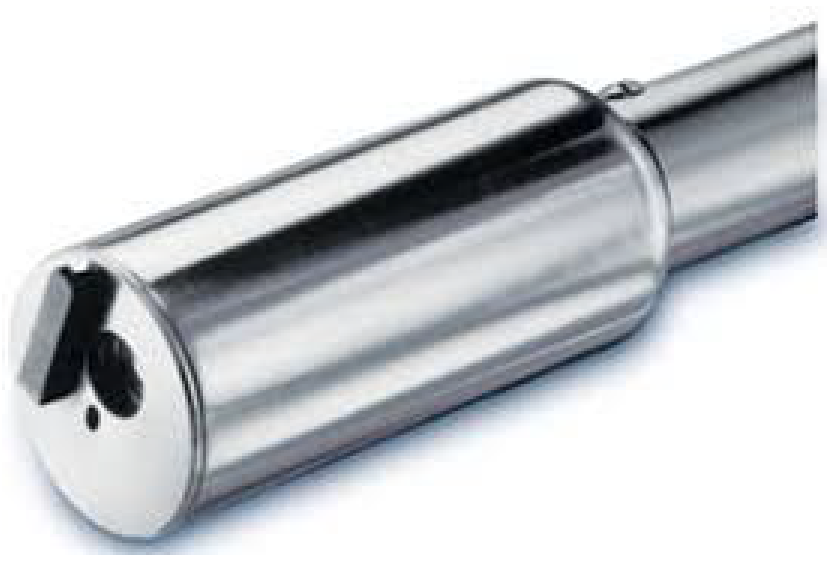

Figure 3. Hach Solitax sc turbidity sensor (used with permission).

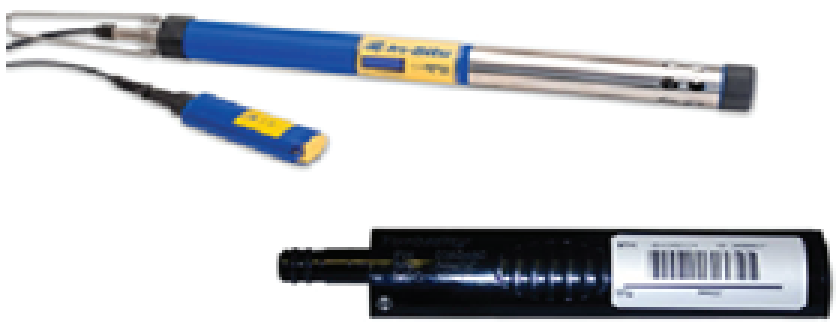

Figure 4. In Situ Aqua TROLL 600 turbidity sensor (used with permission).

2016). Communication to the sonde and sensor was managed through the Winsitu 5 software, version 5.6.29.3. The firmware of the tested sensor was version 1.68.

The OBS501 is a ratiometric turbidity sensor with a single light source with a spectral wavelength of $850 \mathrm{~nm}$ and two photodiode detectors (fig. 5). The first detector is 90 degrees from the light source, and the second detector is positioned to detect light 125 to 170 degrees from the light (Campbell Scientific, Inc., 2017). Biofouling is controlled with a sensor shutter mechanism and a refillable biocide chamber. The OBS501 has three communication modes, SDI-12, RS-232, or analog (0-5 volts), and the operating range of the sensor is from 0 to 4,000 NTU (Campbell Scientific, Inc., 2017). The sn of the OBS used in the study was 1493. Communication to the sensor was through Campbell Scientific's Device Configuration Utility, version 2.16, and firmware version 03 .

The NEP-5000 turbidity sensor by Observator Instruments is a customizable probe. The probe tested in this study was a nephelometric sensor. The sensor has an infrared light source with a spectral wavelength of $850 \mathrm{~nm}$ and a single detector positioned 90 degrees from the light source (fig. 6). The sensor contains a self-cleaning wiper to control biofouling. Communication protocols for the NEP-5000 include digital, RS-422/485, SDI-12, RS-232, universal serial bus, or analog. The sensor was factory calibrated using SDVB standards, and the operating range of this sensor was from 0.01 to 5,000 NTU (Observator Instruments, 2016). Beginning in 2019, all ISO-7027-compliant NEP-5000 sensors purchased through the Hydrologic Instrumentation Facility are now factory calibrated with formazin and prediluted StablCal standards and have an operating range from 0.01 to 4,000 FNU. When operating, the user has the option of using one of three limited calibration ranges (for example, low [0-100 FNU], medium [101-1,000 FNU], or high [greater than 1,000 FNU]) or using the dynamic auto range of the sensor that will switch to the appropriate calibration range automatically. The NEP-5000 tested during the study was sn 108119, firmware version C2 2.024. Initial communication to the sensor was through the Observator Instruments Nephelometer OEM utility, software version C2 2.0027.

Discrete samples were analyzed on the calibrated and verified $2100 \mathrm{~N}$. The $2100 \mathrm{~N}$ has a tungsten lamp with a primary nephelometric detector configuration and an operating range from 0 to 4,000 NTU (Hach Company, 2014). Nephelometric turbidity units are the traditional reporting unit used for a nephelometric designed turbidimeter and are the reporting unit listed in the technical specifications for the $2100 \mathrm{~N}$; however, the $2100 \mathrm{~N}$ is used to validate formazin reference as "truth" during sensor calibration and therefore serves as a valid reference for sensor comparability. For the purposes of this study, nephelometric turbidity units and formazin nephelometric units are interchangeable. The features and specifications of the tested turbidity sensors are listed in table 1.

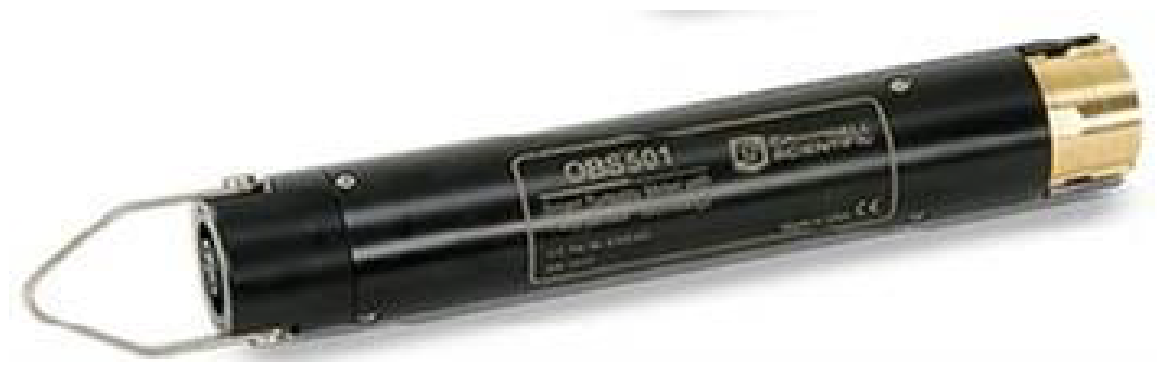

Figure 5. Campbell Scientific OBS501 turbidity sensor (used with permission). 


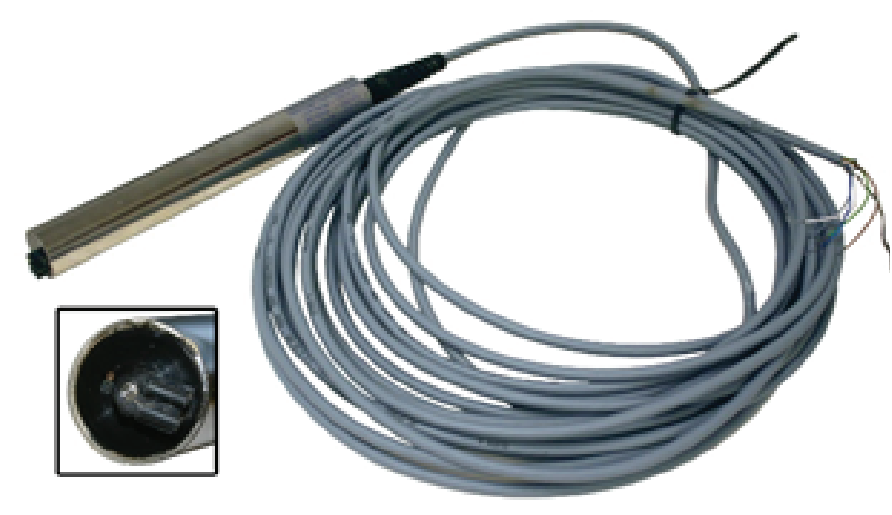

Figure 6. Observator ANALITE NEP-5000 turbidity sensor. Photograph by Nikki Denton, Corps Values (used with permission).

\section{Field Deployment at U.S. Geological Survey Site 02492620 Pearl River at National Space Technology Laboratories Station}

USGS site 02492620 is a well-maintained site at the Stennis Space Center in Hancock County, Miss. Located in a tidally affected reach of the East Pearl River, water at the site is fairly clear with low turbidity (less than $100 \mathrm{FNU}$ ) year round. The suspended sediment concentration is primarily composed of fine particles such as silt and clay. A total of 19 physical and water-quality parameters including turbidity

Table 1. Features and specifications on tested turbidity sensors.

[EXO, Xylem EXO turbidity sensor; Solitax, Hach Solitax sc turbidity sensor; TROLL 600, In Situ Aqua TROLL 600 turbidity sensor; OBS501, Campbell Scientific OBS501 turbidity sensor; NEP-5000, Observator ANALITE NEP-5000 turbidity sensor; FNU, formazin nephelometric unit; NTU, nephelometric turbidity unit; N/A, nonapplicable; \pm , plus or minus; \%, percent; $\leq$, less than or equal to; w.i.g., whichever is greater; ${ }^{\circ} \mathrm{C}$, degree Celsius; USB, universal serial bus; SDI-12, serial data interface at 1,200 baud; RS, recommended standard; nm, nanometer]

\begin{tabular}{|c|c|c|c|c|c|}
\hline $\begin{array}{c}\text { Feature/ } \\
\text { specification }\end{array}$ & EXO & Solitax & TROLL 600 & OBS501 & NEP-5000 \\
\hline Range & 0.01 to $4,000 \mathrm{FNU}$ & 0.01 to $4,000 \mathrm{NTU}$ & 0.01 to $4,000 \mathrm{NTU}$ & 0 to $4,000 \mathrm{NTU}$ & 0.1 to $5,000 \mathrm{NTU}$ \\
\hline $\begin{array}{l}\text { Operating tempera- } \\
\text { ture }\end{array}$ & -5 to $50^{\circ} \mathrm{C}$ & 0 to $40{ }^{\circ} \mathrm{C}$ & -5 to $50{ }^{\circ} \mathrm{C}$ & 0 to $40{ }^{\circ} \mathrm{C}$ & -10 to $40^{\circ} \mathrm{C}$ \\
\hline Self-cleaning & $\mathrm{No}^{2}$ & Yes & $\mathrm{No}^{3}$ & Yes & Yes \\
\hline User calibratable? & Yes & Yes & Yes & Yes & Yes \\
\hline Sensor type & $\begin{array}{l}\text { Nephelometric, } \\
\text { scatter }\end{array}$ & $\begin{array}{l}\text { Ratio sensor, neph- } \\
\text { elometric and } \\
\text { 140-degree back- } \\
\text { scatter }\end{array}$ & Nephelometric, scatter & $\begin{array}{l}\text { Ratio sensor, neph- } \\
\text { elometric and } \\
\text { backscatter }\end{array}$ & $\begin{array}{l}\text { Nephelometric, } \\
\text { scatter }\end{array}$ \\
\hline $\begin{array}{l}\text { Excitation wave- } \\
\text { length }\end{array}$ & $860 \pm 15 \mathrm{~nm}$ & $860 \mathrm{~nm}$ & $855 \mathrm{~nm}$ & $850 \mathrm{~nm}$ & $850 \mathrm{~nm}$ \\
\hline $\begin{array}{l}\text { Sensor configuration } \\
\text { (multiparameter, } \\
\text { stand alone) }\end{array}$ & Multiparameter & Stand alone & Multiparameter & Stand alone & Stand alone \\
\hline
\end{tabular}

1Range based upon three-point calibration with YSI AMCO-Clear standards of 0, 124, and 1,010 FNU.

${ }^{2}$ Vendor recommends installation of sensor onto an EXO2 or EXO3 water-quality sonde with central wiper.

${ }^{3}$ Vendor recommends installation of sensor onto an Aqua TROLL 600 water-quality sonde with central wiper. 
are monitored and updated hourly on the USGS National Water Information System database. The most recent site data are available at U.S. Geological Survey (2018).

Sensor testing was completed at USGS site 02492620 from November 13, 2017, to January 2, 2018. Designed with a programmable pumping system, water at the site is pumped into a white 10-gallon polyvinyl chloride tank. The water is allowed to settle, is tested, and then drains from the tank in 15-minute increments (fig. 7). For the field test, each sensor was fitted with a nylon collar and sensor guard and securely deployed through predrilled holes in a fashioned gray tank lid. This manner of installing the sensors not only protected them from damage but also provided adequate spacing from the sides and bottom of the tank to minimize stray light while ensuring that every sensor measured the same water each time (fig. 8).

Data from the five turbidity sensors were collected at 15-minute intervals. During weekly site visits, the sensors were cleaned to remove accumulated biofouling, and sensor calibration was checked for drift with Type 1 ultrapure deionized water and unexpired 20 and 100 NTU StablCal turbidity standards. Before use, the ultrapure deionized water and StablCal turbidity standards were verified on the $2100 \mathrm{~N}$ for accuracy.

The EXO sensor was installed onto an EXO2 sonde interfaced to a WaterLOG H-522+ XL data collection platform with Geostationary Operational Environmental Satellites transmission. A Hach sc controller was used to verify the Solitax calibration, but during field deployment, the Hach sc controller was bypassed and the Solitax was connected directly to a Campbell Scientific CR6 logger for data collection. Data from the CR6 were retrieved weekly using the cell phone application LoggerLink. The TROLL 600 was deployed independently, and data were logged internally. Data from the TROLL 600 were downloaded weekly during the site visits. The OBS501 and the NEP-5000 were interfaced to a codedivision multiple access Link by Sutron (a division of OTT Hydromet), and data were retrieved weekly using the logger cell phone application LinkComm.

\section{OBS501 Malfunction}

Even though the sensor performance was verified before deployment, the OBS501 malfunctioned early in the testing period. From November 17 to November 22, 2017, the OBS501 turbidity values increased from an average of 10 to 140 FNU. The unit was retrieved on November 22, and the optics were cleared of biofouling that had become lodged under the sensor shutter. After the sensor was cleaned, the measured turbidity returned to an average of 12 FNU. On November 28, the OBS501-measured turbidity again increased to an average of $197 \mathrm{FNU}$. Averaged discrete turbidity during this period was $10.9 \mathrm{FNU}$ when analyzed on the $2100 \mathrm{~N}$. The OBS501 was retrieved and reinspected. Removal of the sliding shutter indicated the optics were again covered in a sticky biofilm (fig. 9). Sensor repair was attempted but was unsuccessful. Because of the failure, only 6 days of OBS501 data were included in the sensor comparison.

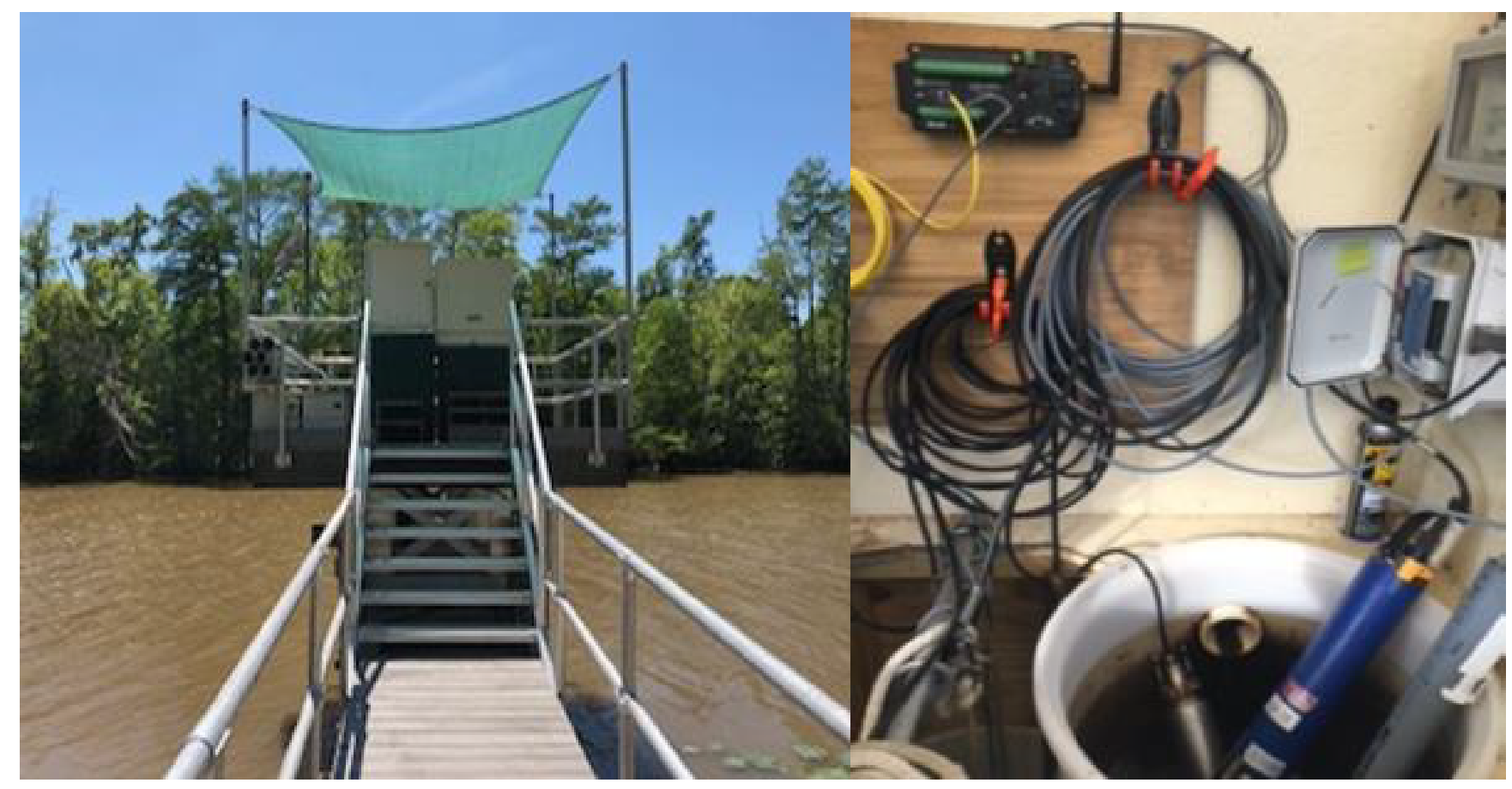

Figure 7. Pearl River at National Space Technology Laboratories Station, Mississippi (U.S. Geological Survey site 02492620), and tank assembly. 


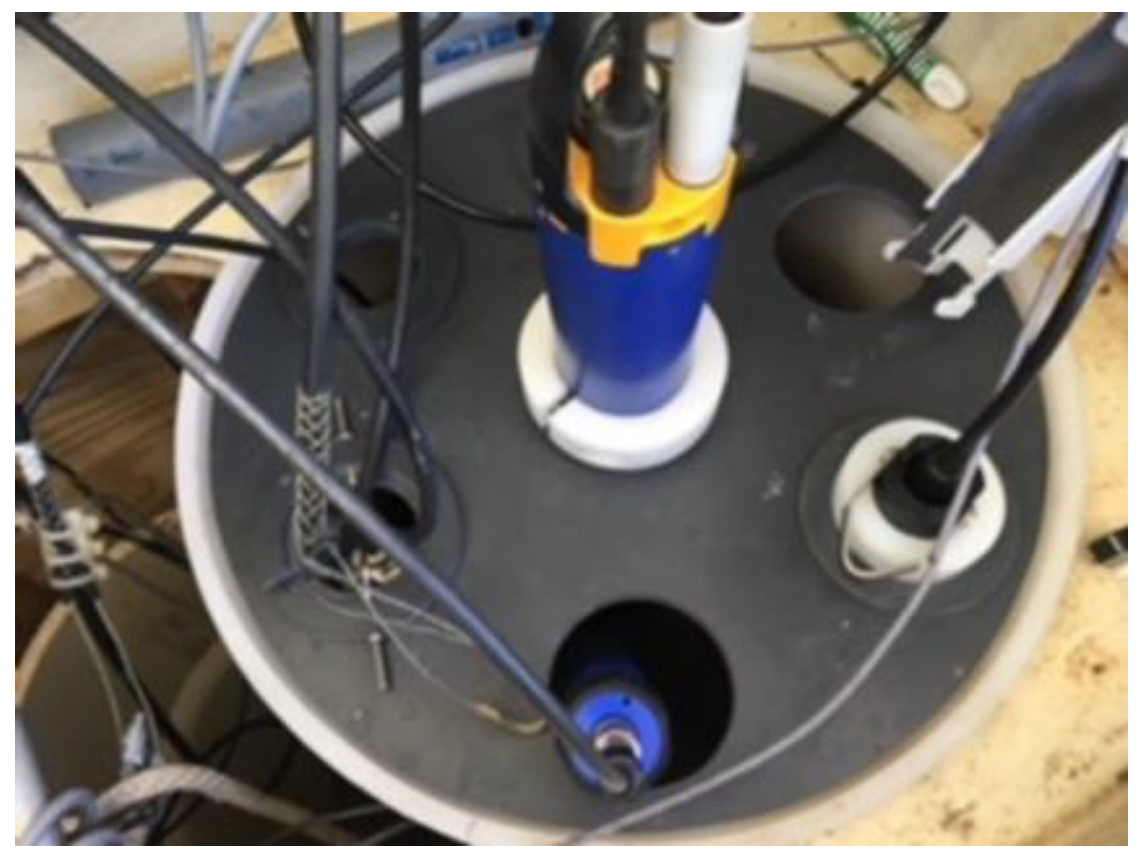

Figure 8. The tank with lid showing predrilled sensor holes.
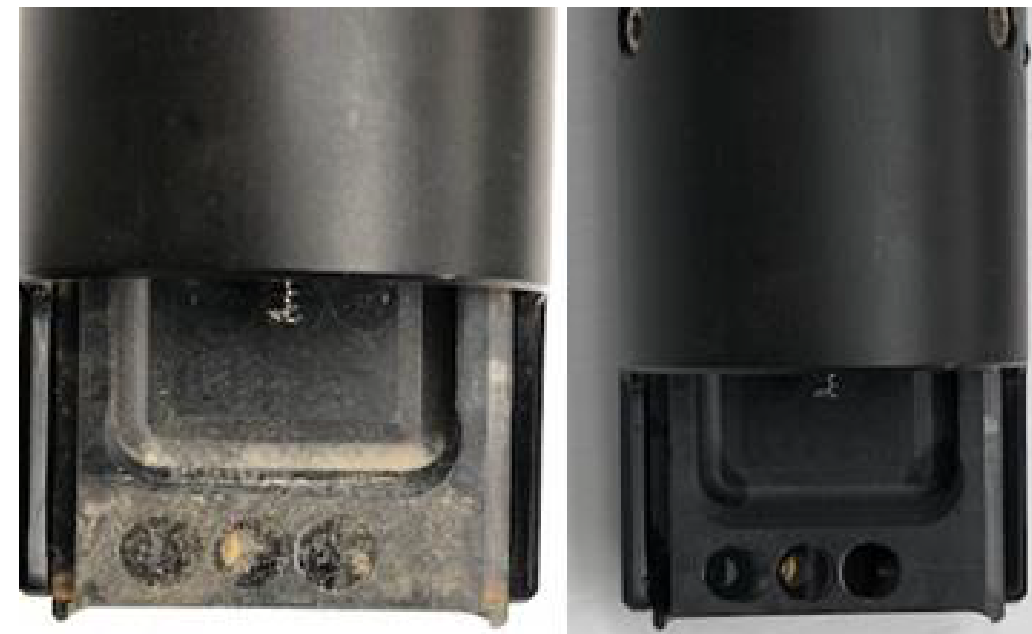

Figure 9. The Campbell Scientific OBS501 turbidity sensor after failure in the field. The photograph on the left shows the condition of the optics after the shutter was removed (precleaned), and the photograph on the right shows the optics after the sensor was cleaned. 


\section{Test Results}

\section{Time-Series Turbidographs}

With the exception of the outliers produced from the OBS501 malfunction, data from the five sensors indicated consistent trending even though occasional spikes in turbidity existed (fig. 10). A comparison of the in situ sensor data to discrete turbidity measured on the $2100 \mathrm{~N}$ indicated agreement as well. In figure 11, the OBS501 data were removed to simplify the interpretation of the remaining data. The pairwise plots of in situ data from the EXO, Solitax, TROLL 600, and NEP-5000 are shown in figure 12 . Interestingly this figure shows the strongest correlation of in situ data between the EXO and the Solitax, with all plots showing increasing scatter in more turbid water.

In table 2, the sensor-measured turbidity values are listed along with the $2100 \mathrm{~N}$-measured discrete turbidity. The differences between the sensors' values and the discrete turbidity were calculated and are also provided in table 2 . The difference was calculated as sensor minus discrete; therefore, negative values indicated lower data as compared to the $2100 \mathrm{~N}$ measurements, whereas positive values indicated higher data. The statistical distribution at 95-percent confidence of this difference data is presented in table 3. The standard error of the mean was calculated as shown in equation 2 :

$$
S E M=\frac{\text { standard deviation }}{\sqrt{\text { sample size }}}
$$

where

SEM is the standard error of the mean.

Combined standard uncertainty was calculated as 5.19 percent based upon the formula provided in equation 3 :

$$
C S U=\sqrt{\text { instrument uncertaint } y^{2}+\text { prep uncertaint } y^{2}}
$$

where

$$
C S U \text { is the combined standard }
$$
uncertainty,

instrument uncertainty is the highest calculated SEM or $1.39 \mathrm{FNU}$, and

prep uncertainty is the 5-percent uncertainty of the 4,000 NTU formazin standard (Joint Committee for Guides in Metrology, 2008).

\section{Statistical Significance}

An analysis of variance (ANOVA) test is used to compare the mean value of more than two groups (Upton and Cook, 2014). A Tukey Honestly Significant Difference (HSD) test compares the means from the ANOVA results and determines if they are significantly different from each other (Colman, 2015). The difference data in table 2 were analyzed with

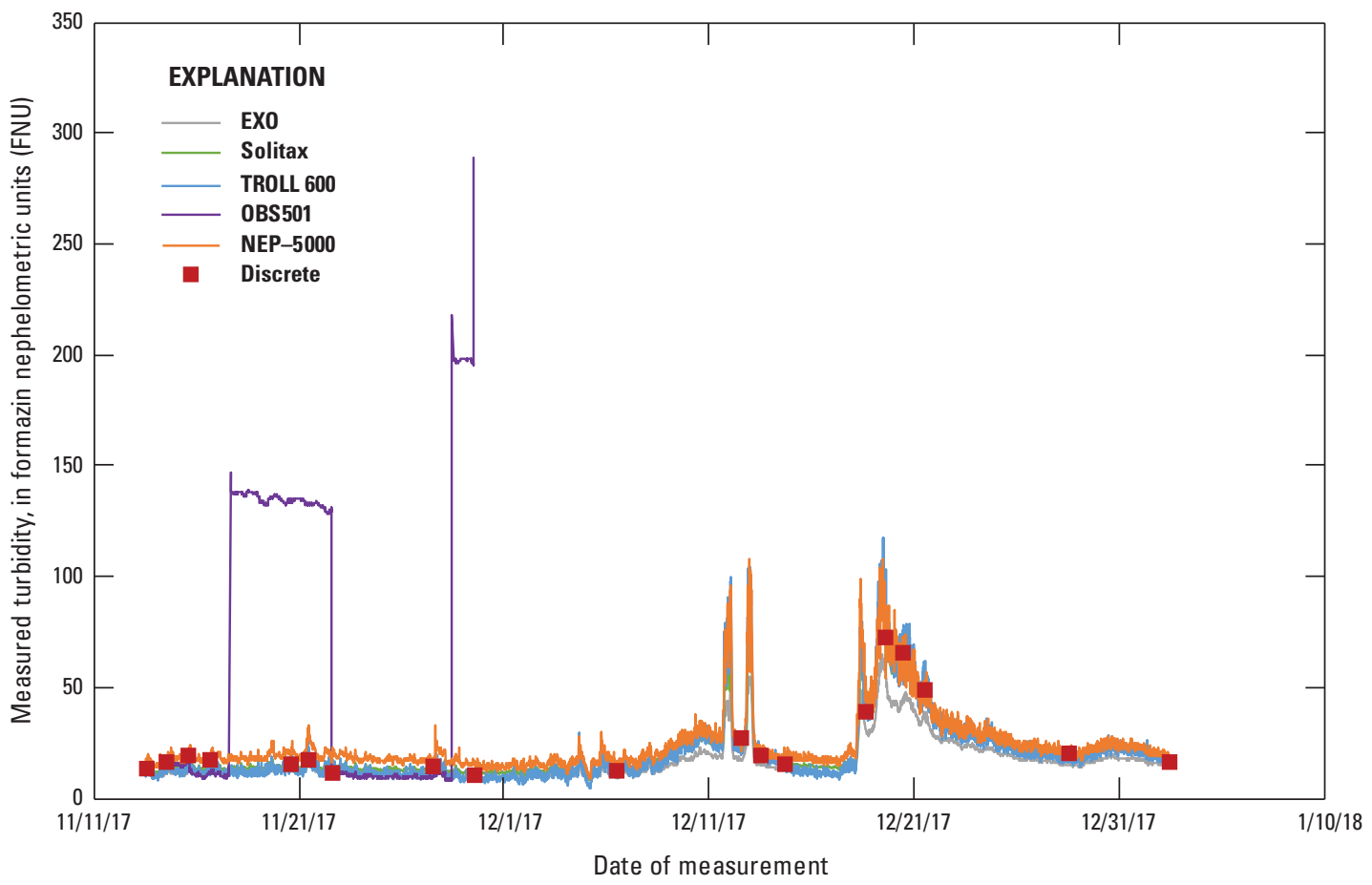

Figure 10. Time series showing the close trending of data produced by the five turbidity sensors. Red squares are the measured turbidity from discrete samples collected concurrently and analyzed on a calibrated benchtop Hach $2100 \mathrm{~N}$ turbidimeter. 


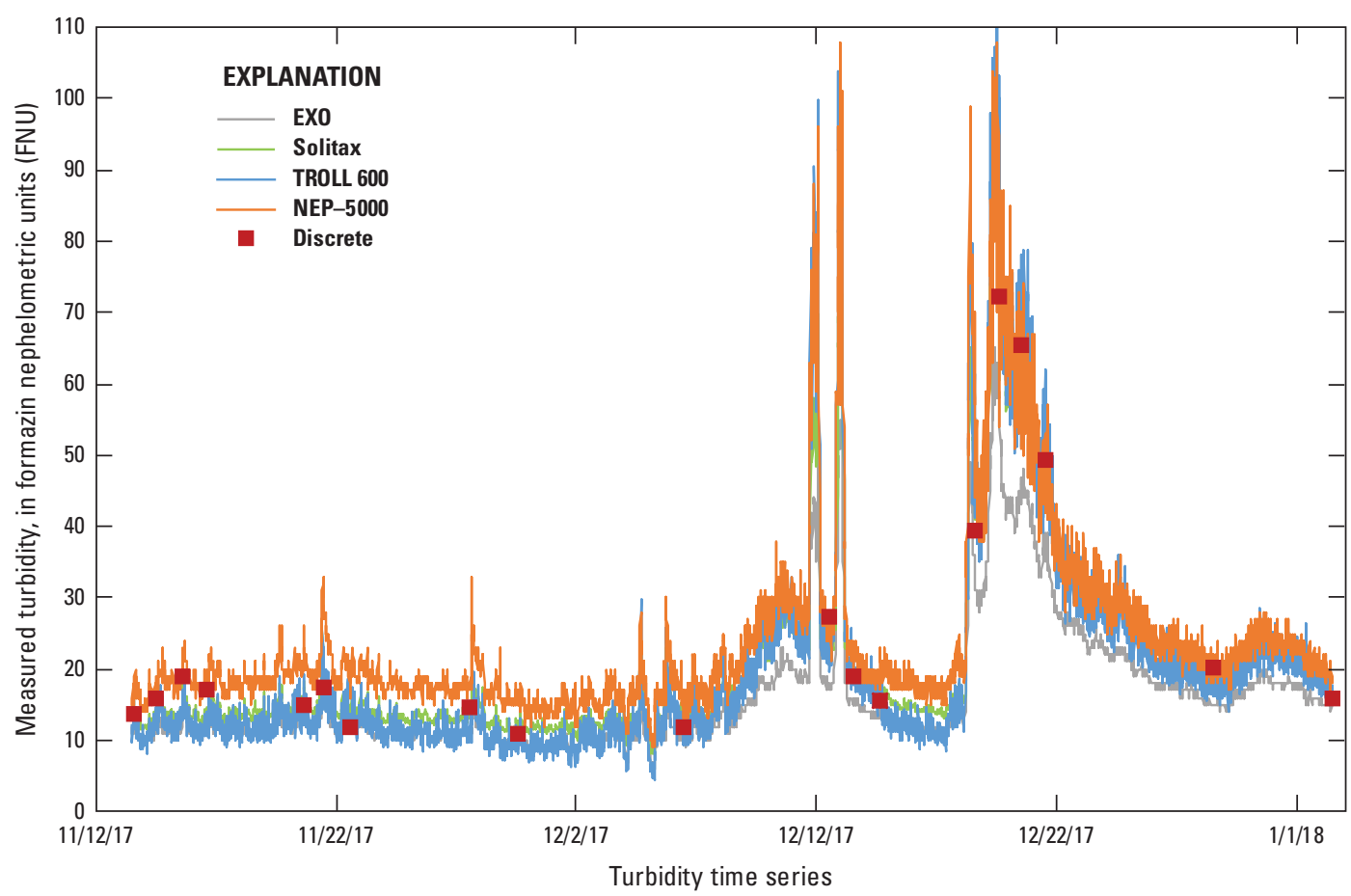

Figure 11. Modified time series showing the data produced by four turbidity sensors after data from the malfunctioning OBS501 was removed. Red squares are the measured turbidity from discrete samples collected concurrently and analyzed on a calibrated benchtop Hach 2100N turbidimeter.

ANOVA and Tukey HSD tests. A summary is provided in table 4. The results from the single factor ANOVA and Tukey HSD tests are provided in tables 5 and 6 , respectively, at 95-percent confidence.

The Tukey HSD test indicated there was a significant difference between the EXO data and data from the other three sensors but an insignificant difference between data from the Solitax, the TROLL 600, and the NEP-5000 as compared to each other. These results did not change when the 5.19-percent combined standard uncertainty was included. During the testing period, EXO data differed from the discrete data by an average of 20.49 percent, and the Solitax data differed from the discrete data by an average of 10.25 percent. The TROLL 600 turbidity differed from the discrete data by an average of 14.17 percent, and the NEP-5000 differed from the discrete turbidity by an average of 11.26 percent. Regression plots for each sensor as compared to the $2100 \mathrm{~N}$ are shown in figure 13, and the plots illustrate the low bias of the EXO data as compared to the other three sensors.

\section{Discussion on Raw Signal Processing}

Like most in situ turbidity sensors, the EXO turbidity sensor has embedded software to filter the real-time data or raw signal (Xylem, 2019). Filtering or raw-data processing is not uncommon among sensor manufacturers, and many of these processes are proprietary. A rolling filter is a moving or sliding average of raw data. For the EXO, Xylem offers optional filtering modes including the default, accelerated, and rapid modes. Default mode averages 40 seconds of (4 Hertz [Hz]) data and is the factory selection for all shipped sensors. The accelerated mode is designed for spot sampling or slow depth profiles and averages 5-10 seconds of $(4 \mathrm{~Hz})$ data. Rapid mode averages $2-3$ seconds of $(4 \mathrm{~Hz})$ data and is designed for rapid depth profiling. In addition to these rolling or averaged filters, the data are also processed with an outlier rejection protocol that further smooths the data. The Solitax and NEP-5000 also have adjustable filtering durations. The Solitax uses a 3 -second averaging filter as its default setting. The default setting for the NEP-5000 is set at a 5 -second averaging filter. The TROLL 600 uses an algorithm that takes three independent turbidity measurements. If the three measurements are within $10 \mathrm{NTU}$ of each other, the measurements are averaged. If the three measurements differ from each other by more than 10 NTU, the median is taken. Unlike the other sensors in the evaluation, the TROLL 600 does not use a rolling filter to incorporate the new measurement with the preexisting turbidity average. 


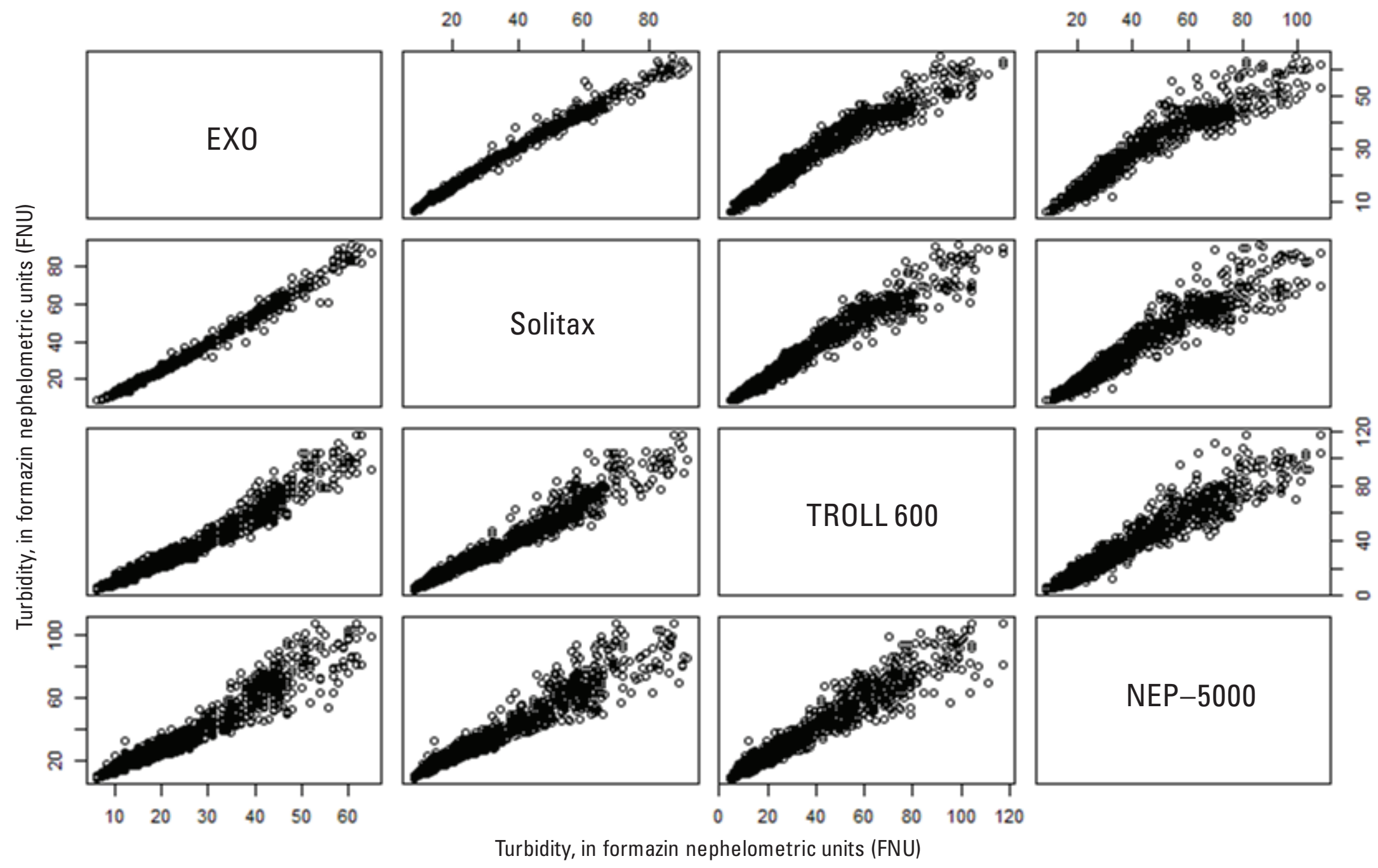

Figure 12. Pairwise plots of in situ data from the Xylem EXO (EXO), Hach Solitax sc (Solitax), In Situ Aqua TROLL 600 (TROLL 600), and Observator ANALITE NEP-5000 (NEP-5000) turbidity sensors showing the correlation to each other. 
Table 2. Discrete turbidity data and corresponding sensor measurements, in formazin nephelometric units. The difference between the discrete data and in situ measurements is also shown.

[Data are from Snazelle (2020). Hach 2100N, Hach 2100N benchtop turbidimeter; EXO, Xylem EXO turbidity sensor; Solitax, Hach Solitax sc turbidity sensor; TROLL 600, In Situ Aqua TROLL 600 turbidity sensor; OBS501, Campbell Scientific OBS501 turbidity sensor; NEP-5000, Observator ANALITE NEP-5000 turbidity sensor; N/A, not applicable]

\begin{tabular}{|c|c|c|c|c|c|c|c|c|c|}
\hline \multirow{2}{*}{$\begin{array}{l}\text { Discrete samples } \\
\text { by Hach } 2100 \mathrm{~N}\end{array}$} & \multicolumn{5}{|c|}{ Measured in situ turbidity } & \multicolumn{4}{|c|}{ Difference from discrete } \\
\hline & EXO & Solitax & TROLL 600 & OBS501 & NEP-5000 & EXO & Solitax & TROLL 600 & NEP-5000 \\
\hline 13.7 & 11 & 13.8 & 12.3 & 13 & 15 & -2.7 & 0.1 & -1.4 & 1.3 \\
\hline 18.9 & 14 & 17.3 & 15.9 & 18 & 19 & -4.9 & -1.6 & -3.0 & 0.1 \\
\hline 17.2 & 12 & 14.4 & 10.8 & 11 & 18 & -5.2 & -2.8 & -6.4 & 0.8 \\
\hline 11.8 & 12 & 13.6 & 13.2 & 10 & 15 & 0.2 & 1.8 & 1.4 & 3.2 \\
\hline 14.5 & 10 & 13.8 & 11.8 & 10 & 17 & -4.5 & -0.7 & -2.7 & 2.5 \\
\hline 10.9 & 10 & 12.1 & 10 & $\mathrm{~N} / \mathrm{A}^{1}$ & 13 & -0.9 & 1.2 & -0.9 & 2.1 \\
\hline 12 & 10 & 12.6 & 11.4 & $\mathrm{~N} / \mathrm{A}^{1}$ & 15 & -2 & 0.6 & -0.6 & 3 \\
\hline 39.5 & 33 & 44.4 & 41.3 & $\mathrm{~N} / \mathrm{A}^{1}$ & 44 & -6.5 & 4.9 & 1.8 & 4.5 \\
\hline 72.3 & 57 & 80.3 & 93 & $\mathrm{~N} / \mathrm{A}^{1}$ & 79 & -15.3 & 8.0 & 20.7 & 6.7 \\
\hline 65.3 & 45 & 60.6 & 74.6 & $\mathrm{~N} / \mathrm{A}^{1}$ & 54 & -20.3 & -4.7 & 9.3 & -11.3 \\
\hline 49.3 & 35 & 47.7 & 55.8 & $\mathrm{~N} / \mathrm{A}^{1}$ & 52 & -14.3 & -1.6 & 6.5 & 2.7 \\
\hline 20.1 & 15 & 18.2 & 16.1 & $\mathrm{~N} / \mathrm{A}^{1}$ & 22 & -5.1 & -1.9 & -4.0 & 1.9 \\
\hline 15.9 & 15 & 17.4 & 17.8 & $\mathrm{~N} / \mathrm{A}^{1}$ & 18 & -0.9 & 1.5 & 1.9 & 2.1 \\
\hline
\end{tabular}

1 No data recorded from OBS501 because of malfunction.

Table 3. Statistical distribution at 95-percent confidence of differences between sensor measurements and Hach 2100N-measured discrete samples, in formazin nephelometric units.

[Data are from Snazelle (2020). EXO, Xylem EXO turbidity sensor; Solitax, Hach Solitax sc turbidity sensor; TROLL 600, In Situ Aqua TROLL 600 turbidity sensor; NEP-5000, Observator ANALITE NEP-5000 turbidity sensor]

\begin{tabular}{lcccc}
\hline \multirow{2}{*}{\multicolumn{1}{c}{ Metric }} & \multicolumn{3}{c}{ Tested sensors } \\
\cline { 2 - 5 } & EXO & Solitax & TROLL 600 & NEP-5000 \\
\hline Mean & -5.66 & 0.39 & 0.86 & 1.24 \\
Standard error & 1.26 & 0.73 & 1.39 & 0.81 \\
Median & -3.9 & 0.1 & -0.7 & 1.9 \\
Standard deviation & 5.51 & 3.18 & 6.1 & 3.55 \\
Minimum & -20.3 & -4.7 & -6.4 & -11.3 \\
Maximum & 0.2 & 8 & 20.7 & 6.7 \\
Count & 19 & 19 & 19 & 19 \\
Confidence level (95.0 percent) & 2.66 & 1.53 & 2.94 & 1.71 \\
\hline
\end{tabular}


Table 4. Statistical summary from the differences between the EXO, Solitax, TROLL 600, and NEP-5000-measured turbidity, and the results of the discrete samples collected concurrently and measured on the Hach $2100 \mathrm{~N}$.

[Data are from Snazelle (2020). All values are in formazin nephelometric units; EXO, Xylem EXO turbidity sensor; Solitax, Hach Solitax sc turbidity sensor; TROLL 600, In Situ Aqua TROLL 600 turbidity sensor; NEP-5000, Observator ANALITE NEP-5000 turbidity sensor]

\begin{tabular}{|c|c|c|c|c|}
\hline Group & Count & Sum & Average & Variance \\
\hline EXO & 19 & -107.5 & -5.6579 & 30.3515 \\
\hline Solitax & 19 & 7.5 & 0.3947 & 10.0983 \\
\hline TROLL 600 & 19 & 16.4 & 0.8632 & 37.2258 \\
\hline NEP-5000 & 19 & 23.5 & 1.2368 & 12.5936 \\
\hline
\end{tabular}

Table 5. Results from the single factor analysis of variance test at 95-percent confidence.

$[F, f$-value; $P$, probability value; $F$-crit, critical value of $F$; N/A, not applicable $]$

\begin{tabular}{lrccccc}
\hline \multicolumn{1}{c}{ Source of variation } & $\begin{array}{c}\text { Sum of } \\
\text { squares }\end{array}$ & $\begin{array}{c}\text { Degrees of } \\
\text { freedom }\end{array}$ & Mean square & $\boldsymbol{F}$ & $\boldsymbol{P}$ & F-crit \\
\hline Between groups & 606.88 & 3 & 202.2931 & 8.964 & $4.03 \mathrm{E}-05$ & 2.7318 \\
Within groups & $1,624.84$ & 72 & 22.5673 & N/A & N/A & N/A \\
Total & $\mathbf{2 , 2 3 1 . 7 2}$ & $\mathbf{7 5}$ & & & & \\
\hline
\end{tabular}

Table 6. Results from the Tukey Honestly Significant Difference test at 95-percent confidence.

[Data are from Snazelle (2020). $Q$, studentized range distribution; $P$, probability value; vs, versus; $<$, less than; EXO, Xylem EXO turbidity sensor; Solitax, Hach Solitax sc turbidity sensor; TROLL 600, In Situ Aqua TROLL 600 turbidity sensor; NEP-5000, Observator ANALITE NEP-5000 turbidity sensor]

\begin{tabular}{lccc}
\hline \multicolumn{1}{c}{ Pairs } & Tukey $\boldsymbol{Q}$ statistic & Tukey $\boldsymbol{P}$ value & Tukey inference \\
\hline EXO vs Solitax & 5.5537 & 0.0010995 & $P<0.05$, significant \\
EXO vs TROLL 600 & 5.9835 & 0.0010053 & $P<0.05$, significant \\
EXO vs NEP-5000 & 6.3264 & 0.0010053 & $P<0.05$, significant \\
Solitax vs TROLL 600 & 0.4298 & 0.8999947 & Insignificant \\
Solitax vs NEP-5000 & 0.7727 & 0.8999947 & Insignificant \\
TROLL 600 vs NEP-5000 & 0.3429 & 0.8999947 & Insignificant \\
\hline
\end{tabular}



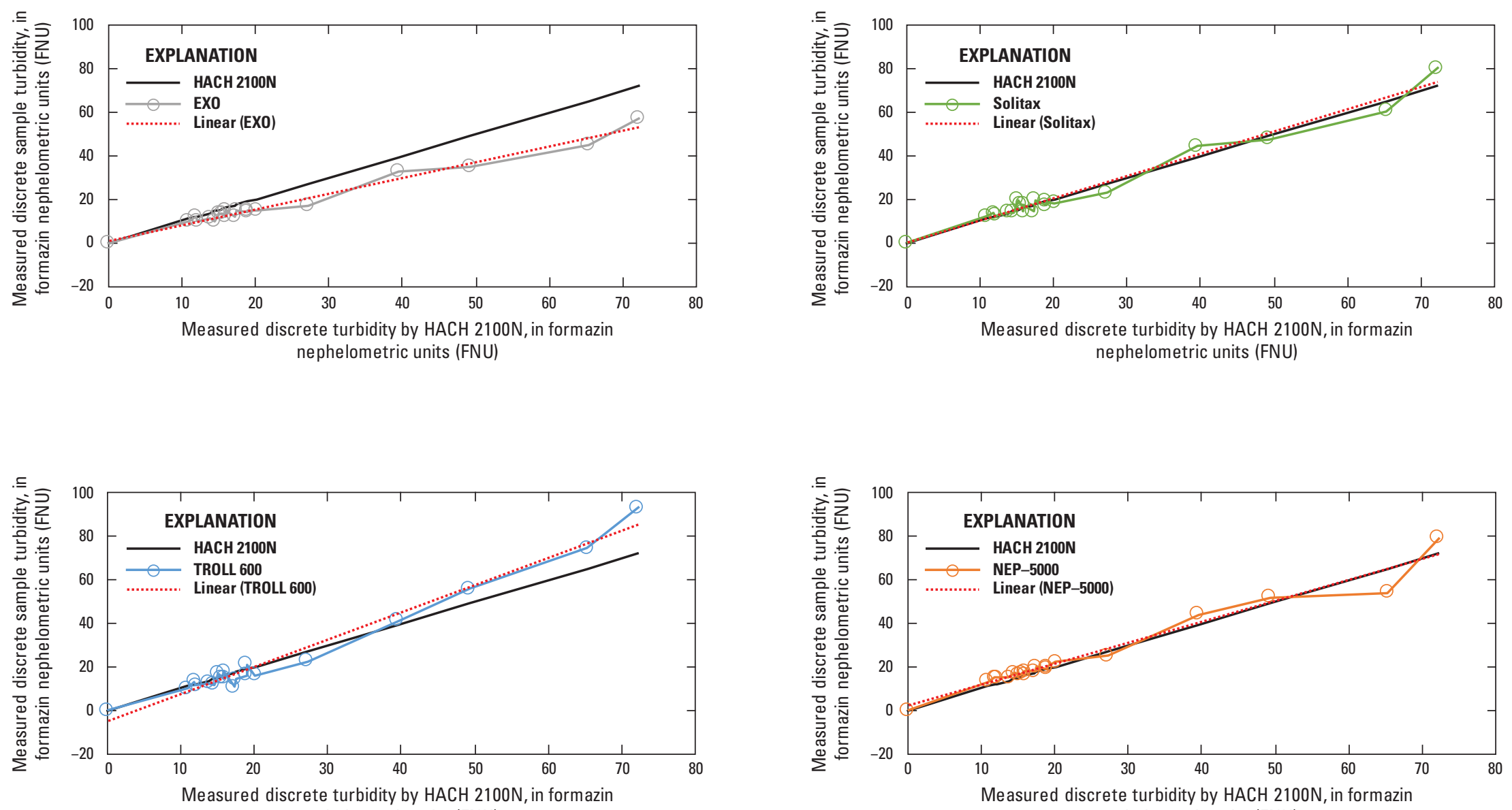

nephelometric units (FNU)

nephelometric units (FNU)

Figure 13. Regression plots comparing in situ turbidity data to the Hach $2100 \mathrm{~N}$-measured discrete turbidity, in formazin nephelometric units. 


\section{Summary}

Five commercially available turbidity sensors were field tested by the U.S. Geological Survey (USGS) Hydrologic Instrumentation Facility for accuracy and data comparability. The tested sensors were the Xylem EXO (EXO), the Hach Solitax sc (Solitax), the In Situ Aqua TROLL sensor installed onto a TROLL 600 sonde (TROLL 600), the Campbell Scientific OBS501 (OBS501), and the Observator ANALITE NEP-5000 (NEP-5000). Sensors were either factory calibrated or calibrated according to the manufacturer's directions with diluted formazin and StablCal prediluted turbidity standards. All calibrations were verified before testing with concentration-verified formazin and StablCal solutions.

The sensors were deployed at Pearl River at National Space Technology Laboratories Station, Mississippi (USGS site 02492620), and were serviced weekly. The turbidity observed at USGS site 02492620 ranged from 5 to 110 formazin nephelometric units, which is not representative of sites with consistent or occasional high turbidity values. In addition to the five in situ turbidity sensors, corresponding discrete samples were collected and analyzed during the evaluation on a calibrated Hach $2100 \mathrm{~N}$ benchtop turbidimeter. The OBS501 malfunctioned early in the evaluation and eventually failed, resulting in few data from the sensor.

Technological advances have resulted in the availability of a variety of turbidimeters designed to meet a variety of objectives; however, differences in instrument design often yield different results when measuring natural waters. During this study, the four remaining sensors (minus the OBS501) changed similarly throughout the field test; however, sensor data from the EXO consistently demonstrated lower results than the Solitax, TROLL 600, and NEP-5000, possibly because of the variation in raw signal processing among manufacturers. Results from a single factor analysis of variance test and a Tukey Honestly Significant Difference test verified the low bias observed in the EXO data and indicated there was a significant difference between the EXO data and data from the Solitax, TROLL 600, and NEP-5000 but an insignificant difference among the data when the Solitax, TROLL 600, and NEP-5000 were compared to each other.

\section{Acknowledgments}

The author thanks Dr. Jacob Gibs (retired), Pat Rasmussen, and Alexandra Etheridge of the U.S. Geological Survey for their guidance with this project.

\section{References Cited}

American Public Health Association, 2012, Standard methods for the examination of water and wastewater (22d ed.): Washington, D.C., American Public Health Association, 1,496 p.

Anderson, C.W., 2005, Turbidity (ver. 2.1, September 2005): U.S. Geological Survey Techniques of Water-Resources Investigations, book 9, chap. A6, sec. 6.7, 52 p., accessed March 2, 2015, at https://doi.org/10.3133/twri09A6.7.

Campbell Scientific, Inc., 2017, OBS501 Smart Turbidity Meter with ClearSensor Technology, operator's manual (revision 10/17): Logan, Utah, Campbell Scientific, Inc., $80 \mathrm{p}$.

Colman, A., 2015, A dictionary of psychology (4th ed.): Oxford, England, Oxford University Press, 896 p.

Gray, J.R., and Glysson, G.D., eds., 2003, Proceedings of the Federal Interagency Workshop on turbidity and other sediment surrogates, April 30-May 2, 2002, Reno, Nevada: U.S . Geological Survey, Circular 1250, 56 p. [Also available at https://doi.org/10.3133/cir1250.]

Hach Company, 2014, DOC022.97.80203, 2100N—Basic user manual (5th ed.): Loveland, Colo., Hach Company, 58 p.

Hach Company, 2017, LIT2472, Solitax sc turbidity \& suspended solids sensors (revision 9): Loveland, Colo., Hach Company, $4 \mathrm{p}$.

Hach Company, 2019, DOC023.9780040 - SC200 controller (10th ed.): Loveland, Colo., Hach Company, 27 p. 
Hughes, A., Davies-Colley, R., and Heubeck, S., 2019, Comparability of ISO 7027 compliant turbidity sensorsNIWA client report 2019125HN: Hamilton, NIWA, 26 p.

In-Situ, Inc., 2016, Aqua TROLL 600 multiparameter sondeOperator's manual (revision 2): Fort Collins, Colo, In-Situ, 125 p., accessed November 2017 at https://in-situ.com/pub/ media/support/documents/Aqua-TROLL-600-Manual.pdf.

International Organization for Standardization, 2016, Water quality - Determination of turbidity-Part 1-Quantitative methods (1st ed.): Switzerland, International Organization for Standardization, 9 p., ISO 7027-1.

Joint Committee for Guides in Metrology, 2008, Evaluation of measurement data - Guide to the expression of uncertainty in measurement: Joint Committee for Guides in Metrology, JCGM 100:2008, 120 p., accessed November 2017 at https://www.bipm.org/utils/common/documents/jcgm/ JCGM_100_2008_E.pdf.

Lewis, J., Eads, R.E., and Klein, R., 2006, Comparisons of turbidity data collected with different instruments: U.S. Department of Agriculture Forest Service, Pacific Southwest Research Station, PSW agreement no. 06CO-11272133-041, 27 p., accessed January 2018 at https://water.usgs.gov/fisp/docs/Tprobe_final_report.pdf.

Observator Instruments, 2016, ANALITE NEP-5000 turbidity sensor datasheet (ver. 102016): Observator Instruments, 5 p., accessed November 14, 2016, at https://observator.com/wp-content/uploads/2019/07/ Datasheet-NEP-5000-V20191216-UK.pdf.
Snazelle, T.T., 2020, Turbidity data collected by five in situ sensors at USGS site 02492620 Pearl River at NSTL station, MS from November 2017 to January 2018: U.S. Geological Survey data release, https://doi.org/10.5066/P9KDERG6.

Upton, G., and Cook, I., 2014, Dictionary of statistics (3d ed.): Oxford, England, Oxford University Press, 468 p.

U.S. Geological Survey, 2018, USGS 02492620 Pearl River At NSTL Station, MS, in USGS water data for the Nation: U.S. Geological Survey National Water Information System database, accessed January 2018 at https://doi.org/ 10.5066/F7P55KJN. [Site information directly accessible at https://waterdata.usgs.gov/ms/nwis/uv?cb_all_00065 00010_70969_00095_00065_00011_99900_00055_00400 $00301 \_00300=$ on\&cb_00065 $=$ on\&cb_00065 $=$ on $\&$ format $=$ gif_default\&period $=7 \&$ site_no $=02492620$.]

Xylem, 2019, EXO user manual-Advanced water quality monitoring platform (revision H): Yellow Springs, Ohio, Yellow Springs Instrument (YSI) Incorporated, 181 p., accessed April 1, 2019, at https://www.ysi.com/File $\% 20$ Library/Documents/Manuals/EXO-User-Manual-Web.pdf.

Ziegler, A.C., 2002, Issues related to use of turbidity measurements as a surrogate for suspended sediment, in Gray, J.R., and Glysson, G.D., eds., Proceedings of Federal Interagency Workshop on Turbidity and Other Sediment Surrogates, Reno, Nev., April 30-May 2, 2002: U.S. Geological Survey Circular 1250, accessed May 1, 2015, at https://doi.org/ 10.3133/cir1250. 

For more information about this publication, contact USGS Water Mission Area

12201 Sunrise Valley Drive

Reston, VA 20192

For additional information, visit

https://www.usgs.gov/mission-areas/water-resources

Publishing support provided by Rolla Publishing Service Center 

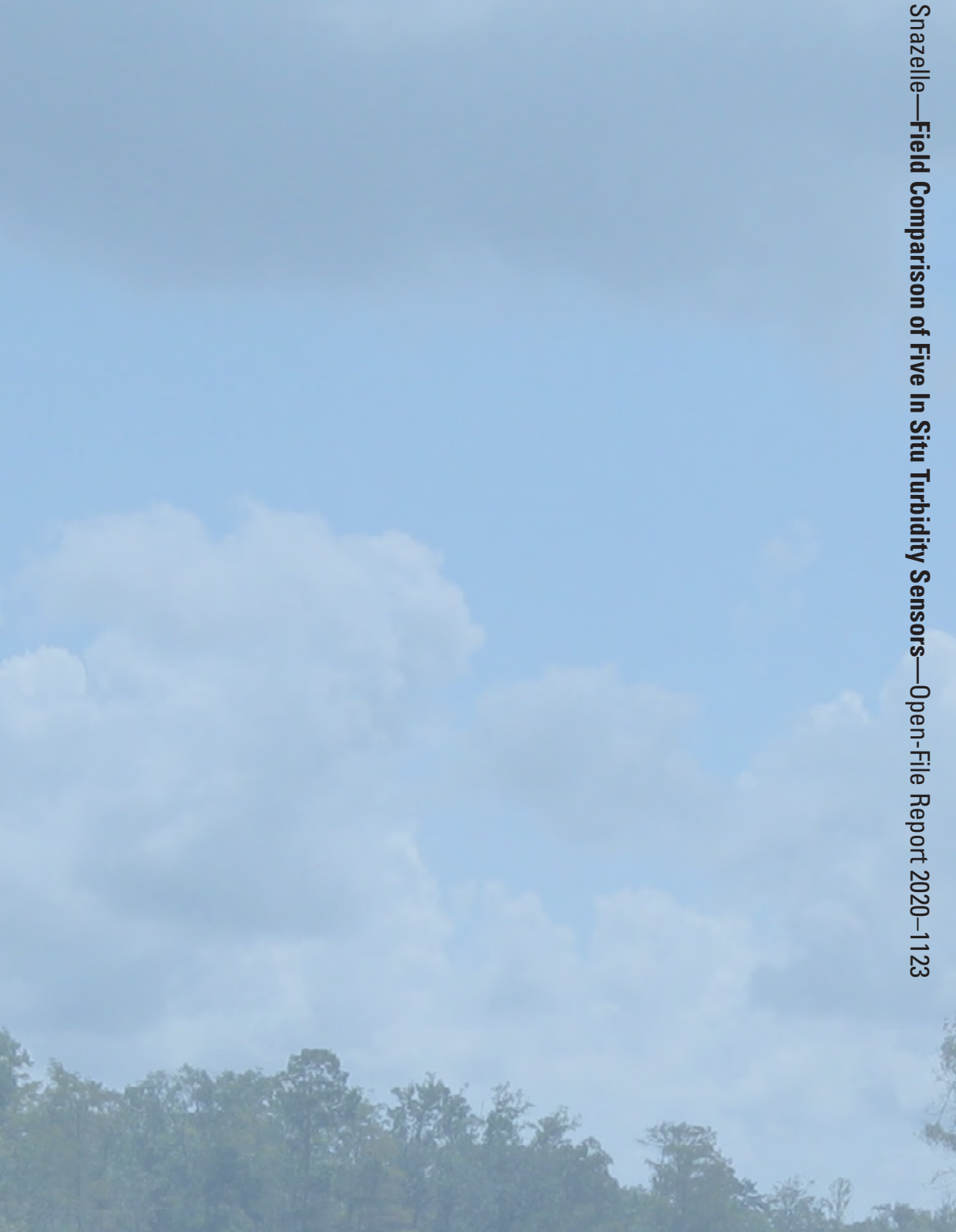